\title{
VALERIJS BITENIEKS - NO RĪGAS POLITEHNISKĀ INSTITŪTA STUDENTA LĪDZ BŪVUZN,ĒMĒJAM NEATKARĪGAJĀ LATVIJĀ
}

ËRIKA LANKA*

Latvijas Universitāte

Kopsavilkums. Pētījums par Rīgas Politehniskā institūta (RPI) Arhitektūras un celtniecības fakultātes absolventu (1986) Valeriju Bitenieku atklāj padomju studentu ikdienu 20. gadsimta 80. gados, jaunā inženiera darbību, izmēǵginot dažādas iespējas darba tirgū un inženiera izaugsmi par veiksmīgu būvuzñēmēju neatkarīgajā Latvijā 21. gadsimtā. Tajā izsekots V. Bitenieka dzīvei no bērnības līdz mūsdienām, pievēršot uzmanību viṇa profesionālajai darbībai. Veicot pētījumu, gūts ieskats par studentu prakses un ārpusstudiju aktivitātēm padomju laikā, iegūti nepublicēti un plašākai sabiedrībai nezināmi fotomateriāli.

Atslēgas vārdi: Valerijs Bitenieks, Rīgas Politehniskais institūts, būvuzṇēmējdarbība.

\section{Ievads}

RPI Arhitektūras un celtniecības fakultātes absolvents (1986), inženieris un būvuzṇēmējs Valerijs Bitenieks pētījumam izvēlēts kā viens no daudzajiem 20. gadsimta 80 . gadu studentiem, lai raksturotu to, kā padomju varas laikā studēja un tika sagatavoti jaunie speciālisti un kā norisa studiju process, jauno speciālistu sadale, kā veidojās diplomēto inženieru karjera. V. Bitenieks studēja vienā no lielākajām augstskolām Latvijā - RPI, un viṇa vārds ir nesaraujami saistīts ar RPI dzīvi un notikumiem Latvijā 20. gadsimta otrajā pusē un 21. gadsimtā. Viṇš piedzīvojis krasas izmaiṇas profesionālajā darbā, vienmēr rodot risinājumu pat vissarežgìitākajās situācijās. V. Bitenieks ir savas Alma

\footnotetext{
* Korespondējošais autors.

E-pasts: erika.lanka@lu.lv 
mater - RPI, tagadējās Rīgas Tehniskās universitātes, inženiera celtnieka profesijas un Latvijas patriots. Par viṇa dzīvi liecina daudzas fotogrāfijas un dokumenti, dal̦a no tiem ar V. Bitenieka ațlauju izmantoti rakstā. Pētījums par vinu veikts, analizējot dokumentus, rakstus, fotoarhīvus un intervējot V. Bitenieku. Raksta mērķis ir atklāt padomju studentu ikdienu 20. gadsimta 80. gados un inženiera V. Bitenieka veikumu un sasniegumus profesionālajā darbībā 20. gadsimta beigās un 21. gadsimta pirmajos 20 gados.

\section{Bitenieka dzimta, bērnība, skolas un pirmās darba gaitas}

Valerijs Bitenieks dzimis 1960. gada 14. janvārī Jakutskā, Jakutijas Autonomajā Padomju Sociālistiskajā Republikā (APSR). Māte Olga Biteniece (dzim. Reutova; 1936-2005) dzimusi Irkutskas apgabala Kačuga (Качyг) ciemā Krievijā, viṇas vecāki nāk no kazaku un burjatu dzimtām. Vairākus gadus Olga ir strādājusi pastā Jakutskā, pēc pārcelšanās uz dzīvi Latvijā bijusi noliktavas pārzine Liepājas dzelzceḷa stacijā [1]. Tēvs Debaldis Bitenieks (1935-2009) dzimis Liepājas apriṇ̣̂ī, Rucavā. Viṇa vecāki ir prūšu dzimtas atvase Margrieta Everte (19151997) un latvietis Mikselis Bitenieks (1897- 1965), kurš 20. gadsimta 20. un 30. gados darbojās Rucavas pagasta valdē [2] un Rucavas kooperatīvā «Pašpalīdzība», tā valdē [3], kā arī krājaizdevu sabiedrībā, 1948. gadā bija kolhoza «Vienība» priekšsēdētājs [4]. M. Bitenieks bija Latviešu strēlnieks, un 1918. gadā, vairoties no vācu okupācijas varas represijām, nomainīja dzimto uzvārdu Bite, kḷūstot par Bitenieku. Viṇš bija pagastā cienīts vīrs, iespējams, tāpēc ǵimeni padomju represijas neskāra.

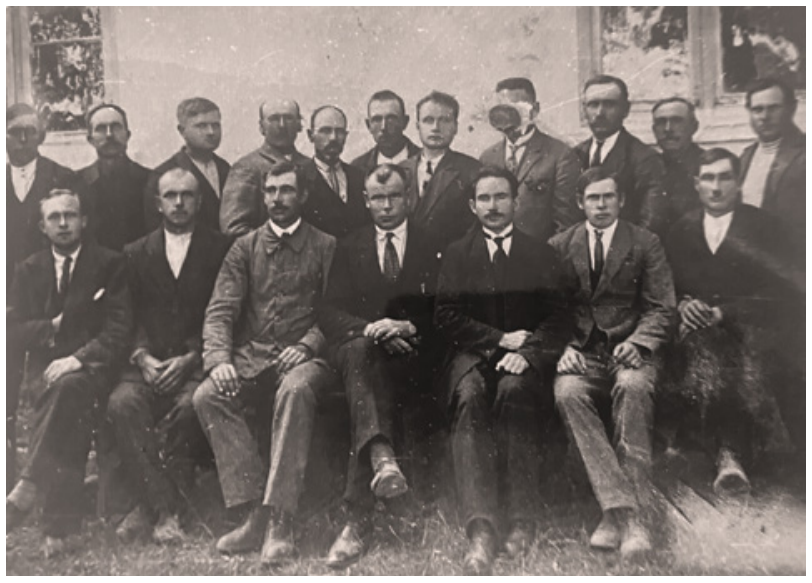

1. attēls. 1. rindā ceturtais no kreisās Mikelis Bitenieks ar Rucavas pagasta valdes locekḷiem (20. gadsimta 30. gadu sākumā). 
Valerija tēvs D. Bitenieks strādājis vairākās profesijās: bijis šoferis, radiomeistars, elektriķis, fotogrāfs, viens no pirmajiem individuālajiem saimniekotājiem laukos, sauktiem par Breša zemniekiem (1989. gada 6. maijā Latvijas PSR Augstākā padome pieṇēma likumu «Par zemnieku saimniecībām Latvijas PSR», kas oficiāli atḷāva paralēli padomju kopsaimniecībām veidot arī individuālās saimniecības. Ministru padomes priekšsēdētājs tobrīd bija Vilnis Edvīns Bresis, tāpēc tos, kuri atbilstoši likumam nodibināja individuālās saimniecības, iesauca par Breša zemniekiem). Viṇš dienēja padomju armijā Sibīrijā, Jakutijas APSR, un tur satika nākamo sievu Olgu.

2. attēls. Olga Biteniece ar Valeriju Rucavā (ap 1961).

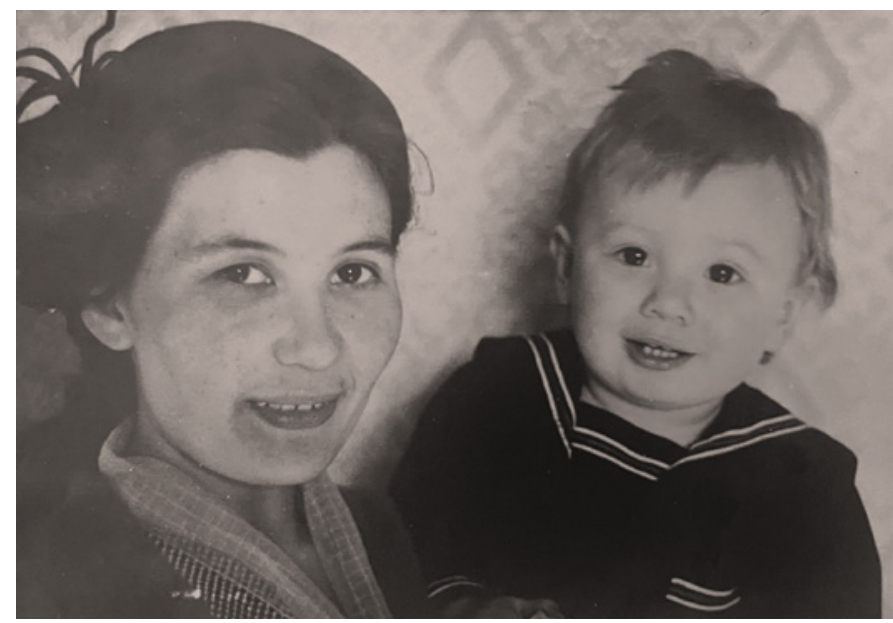

Pirmajā intervijā raksta autorei - $\bar{E}$. Lankai - Valerijs Bitenieks atcerējās vecāku stāstījumu par savu dzimšanas dienu: «Diena, kad es dzimu, bija arī mana tēva otrā dzimšanas diena. Todien viṇam bija jānogādā kāda skolotāja ar skolnieku no ciema uz pilsētu, tas bija apmēram $200 \mathrm{~km}$ pa taigu. Cel̦ā noslāpa motors, jo bākā bija iekḷuvis sniegs. Riskējot apsaldēties $-40{ }^{\circ} \mathrm{C}$ salā, viṇam izdevās iedarbināt motoru un atsākt cel̦u. Taču daḷa degvielas bija iztērēta, lai sasildītos paši un sasildītu motoru, tāpēc līdz pilsētai viṇi netika, un atlikušos 20 km tēvs gāja kājām cauri taigai pēc palīdzības automašīnas saremontēšanai» [5]. Viṇa sieva todien bija devusies uz dzemdībām Jakutskā. Atgriežoties viṇš uzzināja, ka viṇam ir piedzimis dēls. Visi sibīrieši Valerija tēvu Debaldi grūti izrunājamā vārda dēḷ bija iesaukuši par Vaḷeru, tāpēc arī dēlam tika dots šis vārds. RPI dokumentos viṇa vārds ir ierakstīts ar garo patskani «ē» - Valērijs [6]. 


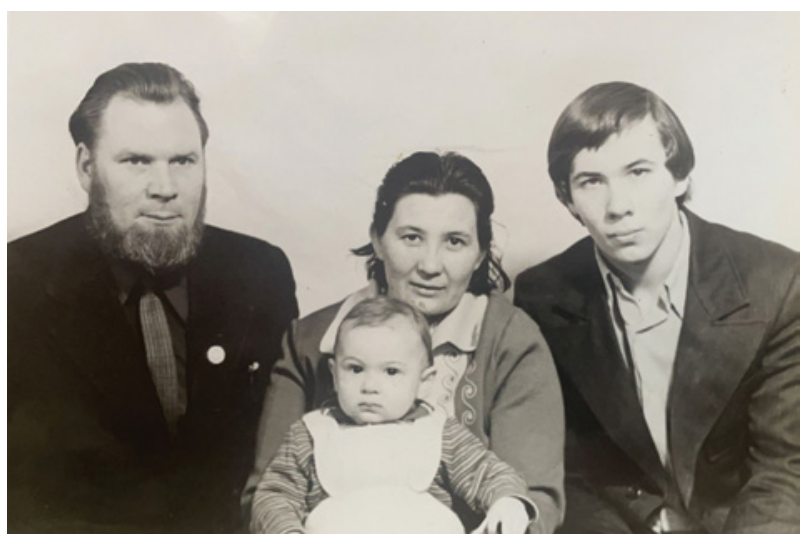

3. attēls.

No kreisās: tēvs Debaldis, māte Olga ar brāli Vairondu klēpī un Valerijs Liepājā (1976).

Pēc dēla piedzimšanas ǵimene nolēma atgriezties Latvijā. Sekoja garš celsš līdz Rucavai, kur Valerijs palika dzīvot pie tēva vecākiem, savukārt viṇa vecāki iekārtojās darbā Liepājā - tēvs par radiomeistaru Karostā, remontējot kara kuǵu aparatūru, māte kḷuva par dzelzceḷa noliktavas pārzini. Tikai tad, kad vecākiem piešksīra istabiṇu Karostas barakās, Valerijam atbrauca pakaḷ uz Rucavu. Puika jau bija sācis runāt, un kādu laiku viṇš savu vecmāmiṇu Margrietu sauca par «pirmo mammu», māti par «otro mammu». Vecāki darba dienās bija darbā, tāpēc Valerijs bieži tika atstāts pie vecmāmin,as, jo bērnudārzā brīvu vietu nebija.

Tikai pirms Valerija skolas gaitu sākuma - 1966. gadā - tēvam piešksīra divistabu dzīvokli tā sauktajā Hruščova laika ēkā, Valerijam vietu bērnudārzā, kuru vinšs apmeklēja vienu gadu līdz kādam incidentam. Audzinātāja esot viṇu iespundējusi vienu pašu vienā no bērnudārza istabām, tāpēc puika sadusmojies un ar slotas kātu izsitis trīs logus.

Līdz 9. klasei Valerijs mācījās Liepājas 11. vidusskolā (1967-1975). Tad V. Bitenieks, tēva sapña un savas vēlmes studēt L,eñingradas (tagad Sanktpēterburgā) Valsts universitātē vadīts, nokārtoja iestājeksāmenus un iestājās Liepājas A. Puškina 2. vidusskolas matemātikas klasē, ko absolvēja 1977. gadā [6], 17 gadu vecumā (tiem, kas mācījās krievu plūsmā, vidusskolā tolaik bija jāmācās 10 gadu (10 klases), latviešu plūsmā - 11 gadu).

Lai iestātos Luningradas Universitātē, vidusskolas atestāta vidējai atzìmei bija jābūt vismaz 4,8, taču Valerijam tā bija zemāka, tāpēc šis sapnis bija izsapnots.

Valerijs pēc vidusskolas iestājās darbā Liepājas rūpnīcā «Liepājmaš», taču jau pēc deviṇiem mēnešiem darbs bija jāpārtrauc. Sasniedzot 18 gadu vecumu, jauniešus, arī V. Bitenieku, iesauca dienestā padomju armijā [6]. 
4. attēls. Liepājas 11. vidusskolas 8. klase. V. Bitenieks garākais 3. rindas labajā pusē.

5. attēls. Liepājas

A. Puškina 2. vidusskolas matemātikas 10. klase. V. Bitenieks - 2. rindā otrais no kreisās (1977).
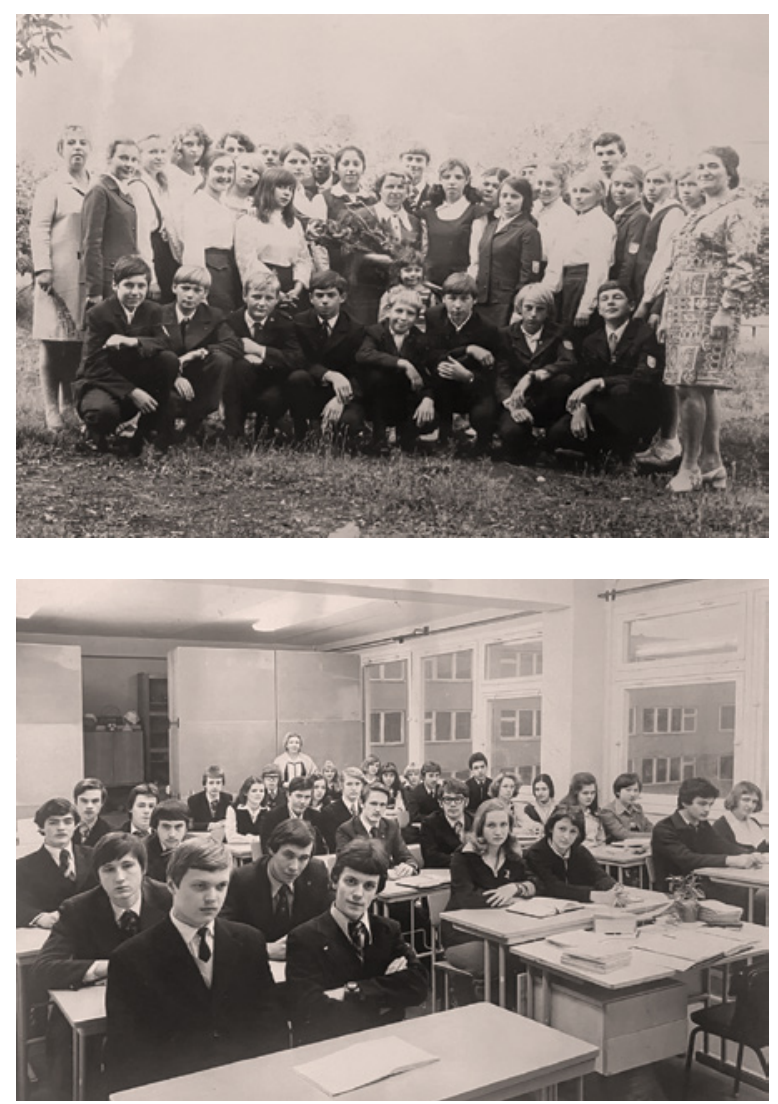

Valerijs

Bitenieks - no

Rīgas Politehniskā institūta studenta līdz būvuznēēējam neatkarīgajā Latvijā

\section{Studijas RPI un būvinženiera gaitu sākums}

No 1978. gada 5. maija līdz 1980. gada 15. maijam V. Bitenieks [6] dienēja Sakaru dạ̣ā Rīgā, Duntes ielā (kur atradās pulks), bet uz dežūrām brauca uz Bukultiem. Nācās piedalīties arī mācībās, ar radiouztvērējiem sekojot NATO bruṇoto spēku vienībām. Tas, pēc V. Bitenieka stāstījuma, esot bijis bīstami un tajā pat laikā iespaidīgi [5].

6. attēls. Māte Olga ar dēliem Vairondu un Valeriju armijas iesaukuma punktā 1978. gada 7. maijā.

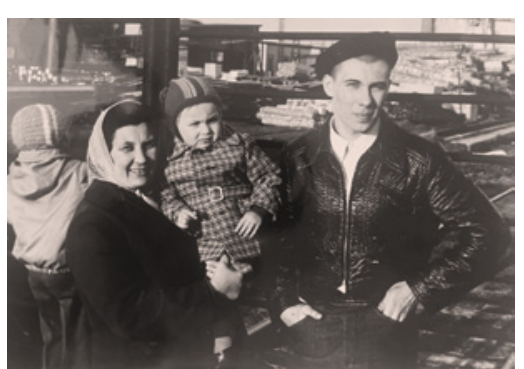




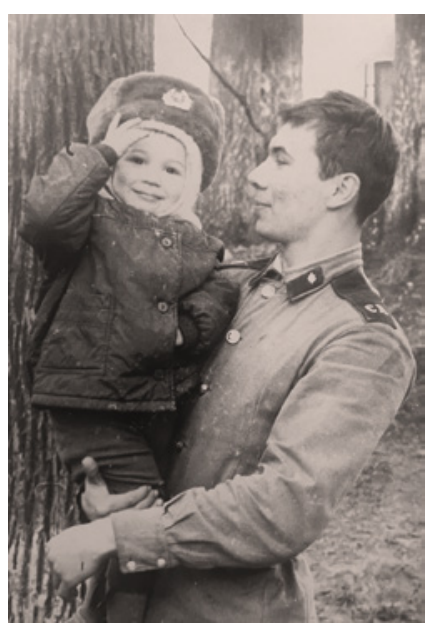

7. attēls. No kreisās: Brāḷi Vaironds un Valerijs Rìgā (1978).

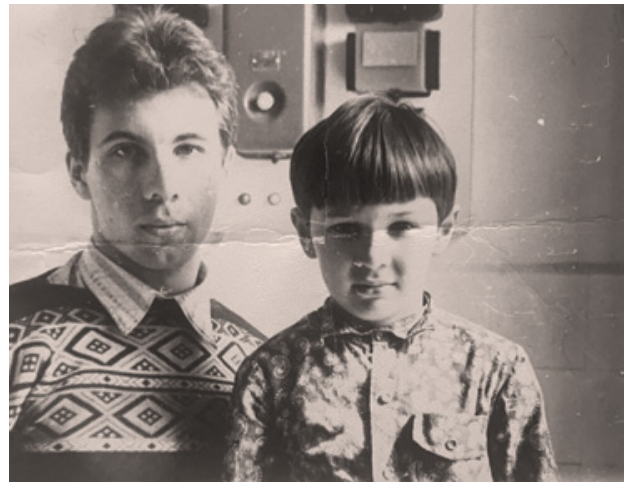

8. attēls. No kreisās: Valerijs Bitenieks un brālis Vaironds Liepājā (1980).

Interese par būvniecību un arī nodoms studēt RPI V. Biteniekam radās pēc atgriešanās no dienesta padomju armijā, kad viṇš 1980. gada jūnijā sāka strādāt būvbrigādē par betonētāju Rietumu elektriskajos tīklos (RET). Tajā vinuu iekārtoja tēvs, kurš tolaik bija RET fotogrāfs. Prakse būvniecībā Valerijam sākās jau 1973. gadā, kad Liepājas ezera krastā, Tebras ielā, vinsš piedalìjās tēva būvētās privātmājas būvniecībā, veicot dažādus palīgdarbus. Par nopelnīto naudu viṇš nopirka divriteni [5].

1980. gada rudenī V. Bitenieks iestājās RPI Liepājas Vispārtehniskā vakara un neklātienes fakultātē Rūpnieciskās un civilās celtniecības specialitātes vakara nodaḷā. Studējot vakara nodaḷā, darba vieta viṇam sesiju laikā piešçīra mācību atvaḷinājumu. 1. kursā tās bija 20 kalendārās dienas [7; 113. lpp.]. Viṇa sekmes eksāmenos 1. kursā bija tikai teicamas. V. Bitenieks strādāja un dzīvoja Liepājā. 1981. gada rudenī V. Bitenieks pārcēlās uz Rīgu un atsāka studēt - šoreiz RPI Arhitektūras un celtniecības fakultātes dienas nodaḷas 1 . kursā. Norīkojumu studijām RPI 
dienas nodaḷā Valērijam deva RET, un viṇam tika piešķirta uzṇēmuma stipendija - 50 rubḷu. Tolaik studentiem bija jāiztur konkurss, lai viṇi tiktu uzn,emti augstskolā, taču ar darbavietu norīkojumiem reflektantus, arī V. Bitenieku, ieskaitīja ārpus konkursa.

Studiju laikā topošajam inženierim bija trīs prakses. 2. kursā bija paredzēta prakse bērnudārza labiekārtošanā. Aizbraucot uz prakses vietu, brigadieris piedāvāja strādāt daudzstāvu ēkas celtniecībā. Valerijs piedāvājumu pieṇēma un aicināja līdzi arī studiju biedru Vitāliju Čmihovu - tagad pazīstamu Latvijas uzñēmēju. Par darbu bija paredzēta akordpremiāla samaksa - par noteiktu darbu norādītajā laikā varēja saṇemt konkrētu naudas summu: katru mēnesi no ķiegeļiem bija jāuzbūvē deviṇstāvu mājas trīs stāvus. Studenti strādāja $+29{ }^{\circ} \mathrm{C}$ karstumā no pulksten 8 līdz 20, un viṇiem nereti no pārpūles reiba galva. Neiztika arī bez negadījumiem - kādu dienu cel̦amkrāna vadītājs aizḳēra tikko uzmūrēto sienu, un tā sabruka. Taču plāns tika izpildīts laikā, un studenti algu - 500 rubḷu - sañēma. Tolaik tā bija liela nauda, jo inženiera alga tajos gados bija apmēram 180 rubḷu mēnesī.

Pēc 4. kursa bija ǵeodēzijas prakse Siguldas bobsleja trases būvlaukumā, kur bija jāierīko trases balsti. Tolaik vēl nebija modernu tehnologiju, un visas atzīmes nācās aprēķināt ar teodolīta palīdzību. Neiztika arī bez kurioziem. Piemēram, darbu vadītājs Ilmārs Brūmanis no Siguldas pārvietojamās mehanizētās kolonnas sekoja un pārbaudīja praktikanta darbu, un reiz, paṇēmis no galda projektu, vin, š ielūkojās Valerija atzīmēs un pārmeta, ka pamatu atzīmes ir nepareizi aprēķinātas - tās vajagot taisīt augstāk. Praktikants iebilda un rādīja savus aprēḳinus. Sākās strīds, līdz vadītājs pamanīja, ka viṇam rokās ir iepriekšējais projekts, kas tapis pirms grozījumu veikšanas. Tā jaunais students novērsa kḷūdu trases celtniecībā.

9. attēls. V. Bitenieks RET būvlaukumā Liepājā (1980).

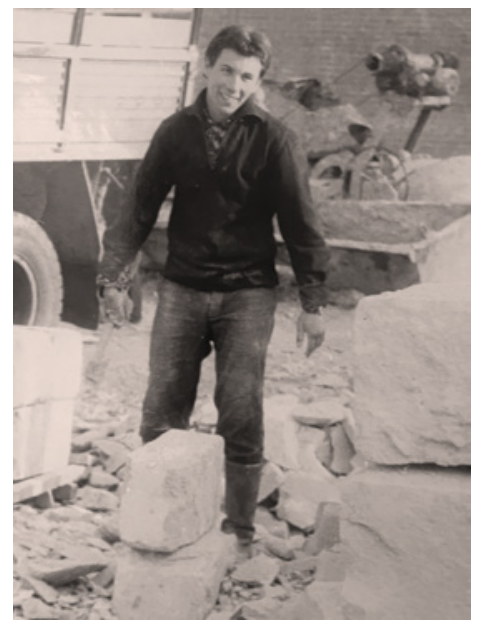

\section{Valerijs}

Bitenieks - no

Rīgas Politehniskā institūta studenta līdz būvuzṇēmējam neatkarīgajā

Latvijā 

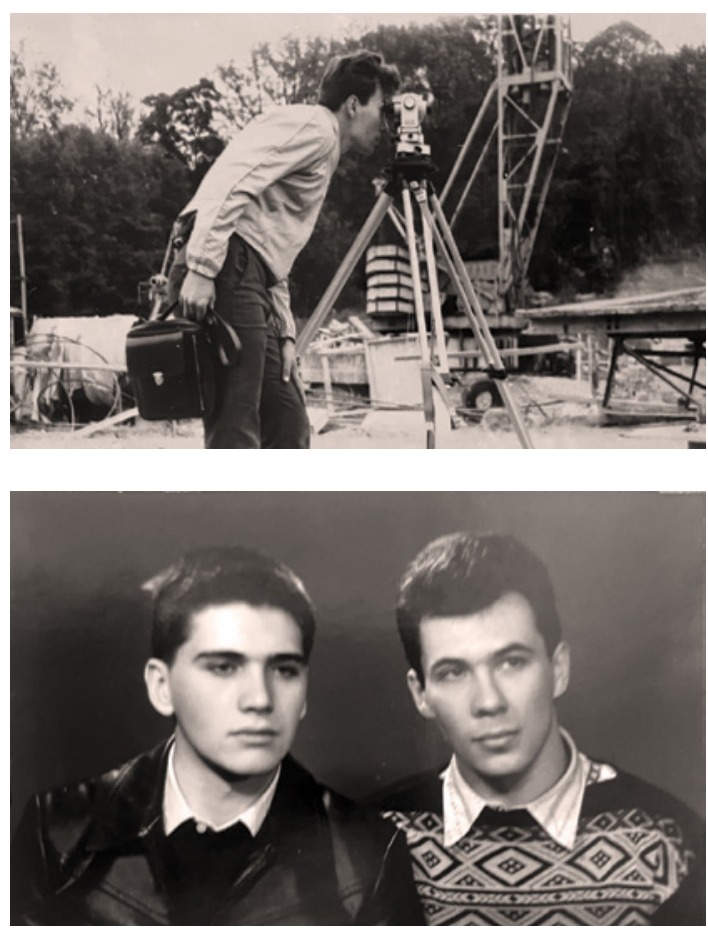

10. attēls. V. Bitenieks RPI geodēzijas praksē Siguldā (1985).

11. attēls. No kreisās: RPI studenti Vitālijs Čmihovs un Valerijs Bitenieks Rīgā (1982).

Nākamā prakse bija Tukuma rajona kolhozā «Dzimtene» - tur vajadzēja betonēt ēku pamatus. Valerijs bija vecāks par citiem un ar armijas dienesta pieredzi, tādēl viṇu iecēla par brigadieri. Brigādē bija studenti no citām grupām, daudzi kavēja darbu, un, lai viṇus ieinteresētu, V. Bitenieks izdomāja t. s. progresīvo atalgojuma variantu: ar katru nākamo darba dienu atalgojums pieauga. Vislabāk apmaksāta bija pēdējā darba diena, taču tikai tiem studentiem, kuri visas dienas pirms tam bija strādājuši. Rezultātā tie, kuri bija strādājuši no pirmās prakses dienas, saṇēma krietni lielāku atalgojumu.

Studentu dzīve RPI ritēja savu gaitu - mācības (V. Bitenieks joprojām novērtē studiju laikā gūto zināšanu pamatīgumu un noderīgumu visai dzīvei un darba karjerai), prakses, sesijas ar pārbaudījumiem, studentu dzīve kopmītnēs ar diskotēkām no studijām brīvajos brīžos.

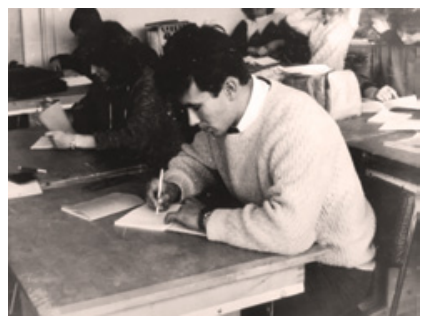

12. attēls. V. Bitenieks RPI auditorijā Kūpsalā (ap 1983). 
13. attēls. No kreisās: Valerijs Bitenieks, nezināmā persona un Vitālijs Kadišs pie RPI centrālā korpusa Strēlnieku laukumā (1982).

14. attēls. RPI studentu kopmītnēs Rīgā, Iḷguciemā, Olaines ielā 4 (ap 1982).

15. attēls. V. Bitenieks kartupel̦u talkā (1981).

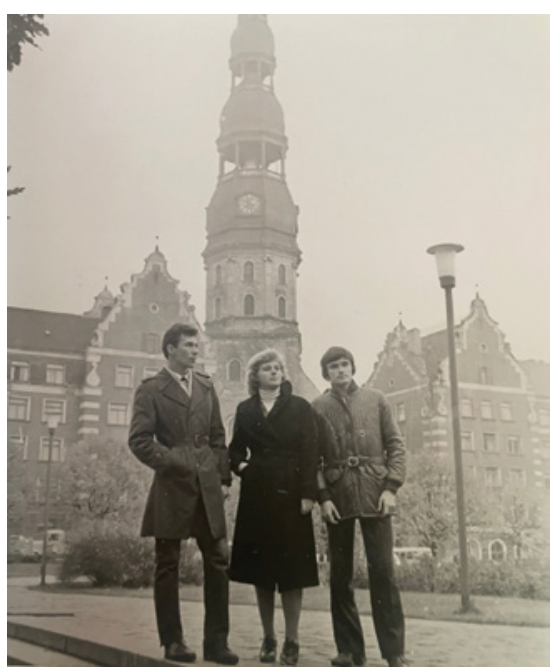

\section{Valerijs}

Bitenieks - no

Rīgas Politehniskā

institūta studenta

līdz būvuznēmējam

neatkarīgajā

Latvijā
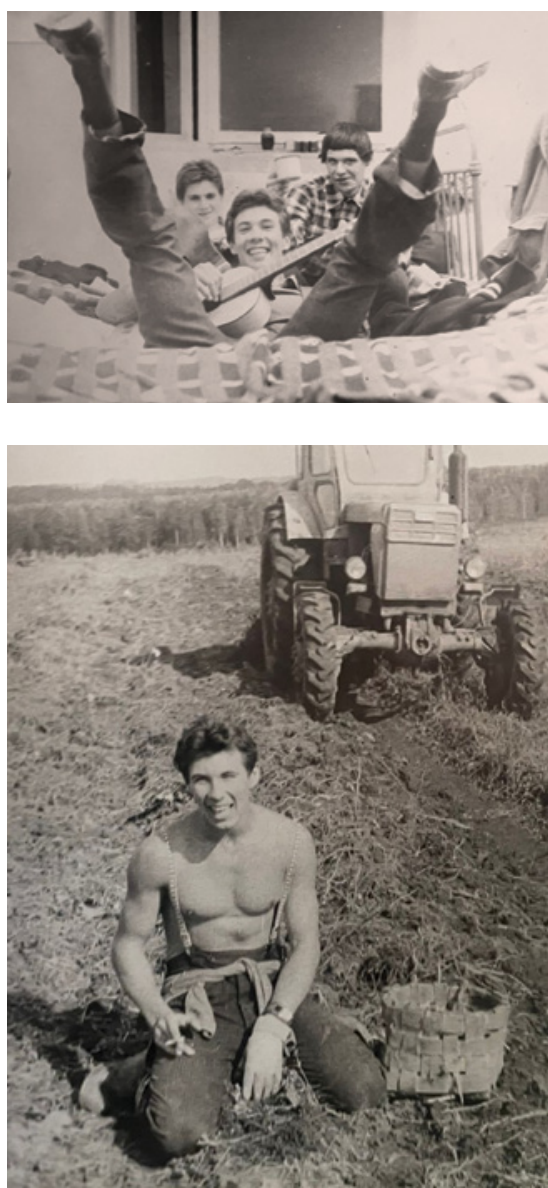
Studiju laikā, 2. kursā, bija arī kāds nepatīkams starpgadījums. V. Bitenieks uz praktisko nodarbību būvmateriālu mācībā ieradās ar krietnu nokavēšanos - tikai uz tās otro dalı. Kontaktēšanās ar mācībspēku bija nepatīkama. Students uzskatīja, ka viṇam aiz muguras ir prakse un viṇš praktisko darbu paveiks godam, savukārt mācībspēks vēlējās, lai studenti ir disciplinēti. Pēc mācībspēka ziṇojuma V. Bitenieka uzvedība tika izskatīta Arhitektūras un celtniecības fakultātes Mācībuaudzināšanas komisijas sēdē, pēc tam - arī fakultātes komjaunatnes biroja sēdē, jo V. Bitenieks, kā vairums toreizējo studentu, bija komjaunietis. Viñam tika izteikts rājiens. Students V. Bitenieks jau toreiz uzskatīja, ka labu speciālistu sagatavošanu garantē ne tikai $100 \%$ nodarbību apmeklēšana. Inženieris V. Bitenieks joprojām uzskata, ka studenti mācās sev un katram pašam kritiski jāizvērtē, ko viṇš prot un var, kā arī lietderīgi jāizmanto laiks. Toreiz, domājams, pietrūka zināšanu komunikācijā gan studentam, gan docētājam, jo visu varēja atrisināt bez citu cilvēku iejaukšanās. Atceroties studiju gadus, V. Bitenieks sarunā ar RTU profesori Alīdu Zigmundi novērtēja RPI mācībspēku profesionalitāti un atzina, ka galvenā viṇu vēlme bija, lai studenti gūtu izpratni par konkrēto studiju priekšmetu. V. Bitenieks atcerējās faktu, ka viṇš paredzētajā laikā neuzrakstīja pārbaudījumu matemātikā, tāpēc starp studentu un mācībspēku notika diskusija. V. Bitenieks izstāstīja, kā vin,š uzdevumu risinātu un saṇēma pozitīvu vērtējumu [8].

1986. gada 16. jūnijā V. Bitenieks sanēma inženiera celtnieka diplomu rūpniecības un civilās celtniecības specialitātē [6]. Toreiz RPI absolventi bija cerību pilni un droši par savu nākotni: darbu garantēja tā sauktā valsts sadale. Un neviens pat nenojauta, ka tuvojas lieli pārmainu laiki. Daḷa kursabiedru devās strādāt uz ārzemēm, taču Valerijs izvēlējās palikt Latvijā.

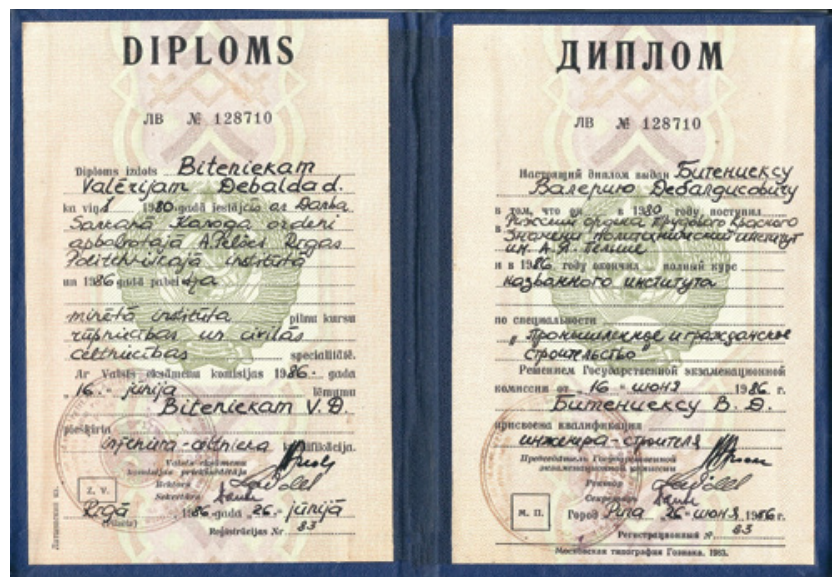

16. attēls. RPI absolventa V. Bitenieka diploms (1986). 


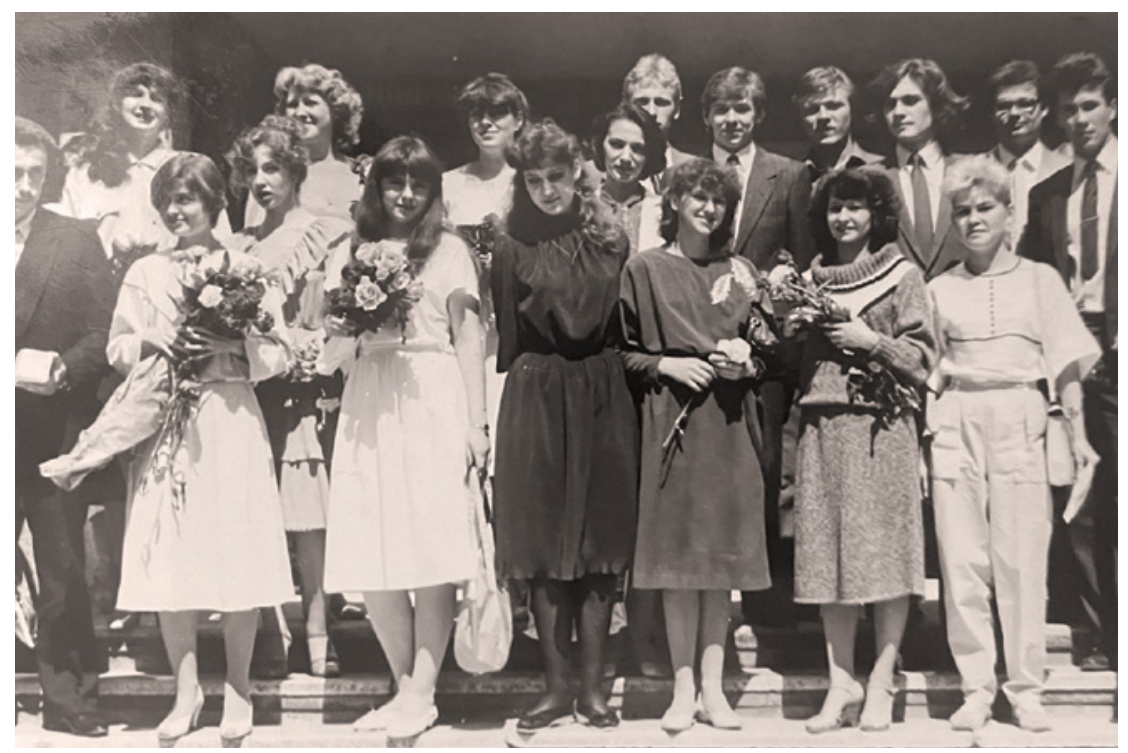

17. attēls. RPI rūpniecības un civilās celtniecības specialitātes K3 grupas absolventi. 2. rindā pirmais no labās V. Bitenieks Rīgā, uz Āzenes ielas ēdnīcas kāpnēm (1986).

Karaklausībai pakḷautajiem studentiem pirmajos četros studiju gados, vienu dienu nedēḷā bija obligātā militārā apmācība. Studenti kārtoja kursa eksāmenus militārajos priekšmetos, 30 dienas pavadīja militārajās nometnēs armijas daḷās un mācību noslēgumā kārtoja eksāmenu [7; 96. lpp.]. 1985. gada vasarā RPI studentus nosūtīja uz militāro nometni Klogā, Igaunijā. Arī šī nometne («сборы») bija paredzēta PSRS bruṇoto spēku stiprināšanai ar kvalificētiem kadriem.

18. attēls. Jaunākais leitnants V. Bitenieks pēc eksāmena militārajā nometnē Klogā (1985).

\section{Valerijs}

Bitenieks - no

Rīgas Politehniskā institūta studenta līdz būvuznēmējam neatkarīgajā Latvijā 


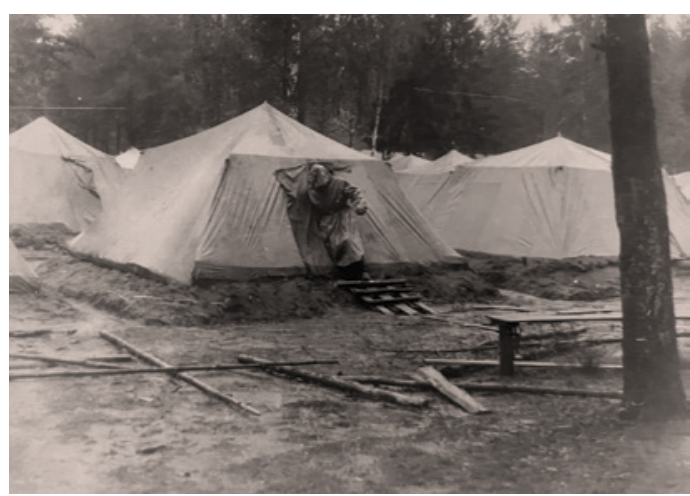

19. attēls. V. Bitenieks RPI studentu militārajā nometnē Klogā (1985).

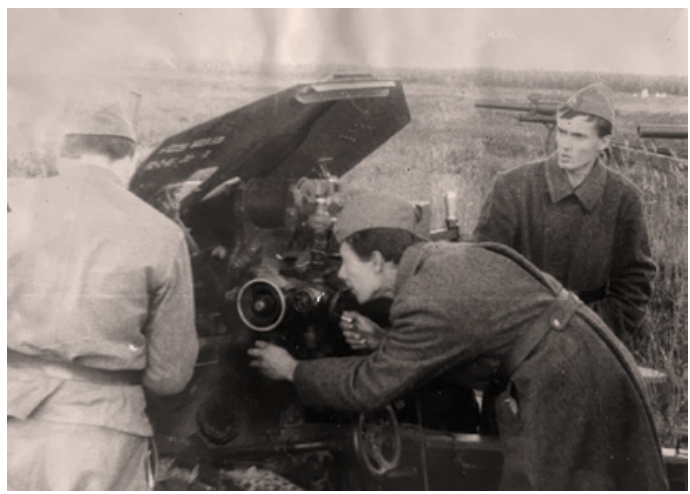

20. attēls. RPI studenti eksāmena laikā militārajā nometnē Klogā. No kreisās: Valerijs Bitenieks un Vitālijs Kadišs (1985).

\section{Darba gaitas, gimene, ekonomikas izaicinājumi un pārbaudījumi}

Pēc studijām RPI V. Biteniekam kā uzṇēmuma stipendiātam vajadzēja atgriezties RET Liepājā. Tas nozīmēja, ka būtu jādzīvo kopā ar vecākiem. Valerijs izlēma, ka savu patstāvīgo dzīvi sāks tālāk no viṇiem un izlūdzās norīkojumu uz Vissavienības komjaunatnes triecienceltni Kanskas Ačinskas termoelektrostaciju kompleksu (KATEK) Sibīrijā. To Padomju Savienībā daudzināja par energètikas «lielvalsti» [9]. Milzīgajā kompleksā būvēja elektrostacijas, kas darbojās, izmantojot brūnogles. Sākumā jaunieti aizrāva mērogi un vēriens, ar kādu tur viss notika, taču jau pēc gada viṇš bija krietni vīlies, jo cilvēki, kas tur strādāja, bija ļoti dažādi. Pēc pāris gadiem V. Biteniekam izdevās atbrīvoties no jaunā speciālista statusa un pāriet "parastā strādnieka» statusā un tad - pēc paša vēlēšanās - atbrīvoties no darba.

20. gadsimta 80. gadu studenti, tostarp arī V. Bitenieks, gimenes dibināja jau studiju gados. Un uz Sibīriju viṇš devās kopā ar ǵimeni sievu un meitu Lindu [5]. Intervijā Ē. Lankai Valerijs vairākkārt uzsvēra, 
ka sieva ir viṇa dzìves uzticamais un drošais atbalsts, iedvesma, partneris, draugs, brīnišķīga bērnu māte un sieva. Kopdzīves pirmajos gados, dzìvojot Sibīrijā, jaunais speciālists Valerijs ar sievu un meitu dzīvoja kopmītṇu tipa $12 \mathrm{~m}^{2}$ istabiṇā. Sieva iekārtojās darbā vietējā bibliotēkā un vinu cienīja plašā apkaimē, vietējās avīzēs pat publicēti raksti par viṇu. Atšķirībā no Valerija sievai darbs patika un viṇai bija žēl to pamest. Taču bija gaidāms otrs bērns, un ǵimene nolēma atgriezties Latvijā. 1988. gada martā Bitenieki ieradās Latvijā, un jūnijā viṇiem piedzima otra meita Lelde. Valerijs sāka strādāt eksperimentālajā ražošanas laboratorijā «Sigfarm» par celtniecības iecirkṇa inženieri.

Bitenieku ǵimenes atgriešanās no Sibīrijas notika Latvijai nozīmīgā laikā - 1988. gada 1. un 2. jūnijā Rīgā notika Radošo savienību plēnums, un pirmo reizi skaidri un skaḷi izskanēja vēlme atgūt Latvijai neatkarīgas valsts statusu. Jūlijā notika politiskās organizācijas «Latvijas Nacionālās neatkarības kustība» dibināšanas kongress [10], kurā piedalījās arī V. Bitenieks ar kolēǵiem. Pēc kongresa vinš atdeva ārstam un politiksim Jānim Straumem savu rezerves virsnieka kara apliecību, ko saṇēma studiju laikā pēc militārās nometnes Klogā, Igaunijā. Vēlāk V. Bitenieks kopā ar V. Čmihovu piedalījās pasākumos, ko organizēja Latvijas Atmodas laika sabiedriski politiska kustība un organizācija «Latvijas Tautas fronte», piemēram, tautas akcijā «Baltijas cel̦š» 1989. gada 23. augustā, 1991. gada janvārī devās uz barikādēm, kā arī kopā ar sievu bija manifestācijā «Par neatkarīgu Latviju» Daugavmalā 1989. gada 18. novembrī. Sevi V. Bitenieks raksturo šādi: «Pats esmu politiski un nacionāli neitrāls - nestājos nevienā partijā, un, kaut arī esmu ticīgs, nevienā baznīcā neeju. Smejos, ka esmu krievs - latviešu nacionālists. Un arī ticībā man tuvāks ir budisms. Esmu arī pacifists [5].»

1989. gada nogalē V. Bitenieks kopā ar draugu, RPI absolventu V. Čmihovu nodibināja kooperatīvu «Bild». Vitālijs bija tā priekšsēdētājs, savukārt Valerijs uzṇēmās kārtot grāmatvedības jautājumus. Kooperatīvs strādāja zvēraudzētavas saimniecības «Gauja» paspārnē, un tika iegādāts pirmais objekts - kokzāge ètava. Tā vairāk tika remontēta, nekā strādāja, un tajā nebija arī speciālistu. Par visu nācās domāt pašiem.

Tajā pašā laikā V. Bitenieka tēvam - Breša zemniekam - izdevās saṇemt lielu valsts kredītu lopu fermas būvniecībai. Talkā tika aicināts dēls kā diplomēts celtnieks. Valerijam nācās atvadīties no kooperatīva un pārcelties pie tēva, lai īstenotu lielos plānus. Taču pēc Latvijas rubḷa ieviešanas 1992. gadā visus biznesa plānus nācās atlikt, - atcelt pavisam, jo līdz ar robežu slēgšanu ar Krievijas Federāciju visām iecerēm nopelnīt austrumu kaimin,valstī bija pielikts punkts. 90. gadu sākumā bija jādomā par ko citu, jo radās iespēja eksportēt preces uz Eiropu. V. Bitenieks pievērsās kokmateriālu ieguvei, taču ilgi tas 
neturpinājās - kokmateriālu cenas Latvijā tikai sākumā strauji kāpa, tad, pieaugot konkurencei, tikpat strauji saruka.

1995. gadā V. Bitenieks atgriezās Siguldā, jo saprata, ka celtniecības inženierim jāatrod cita nodarbošanās. Meklējot darbu, viṇš atsaucās piedāvājumam vadīt nelielu metāla darbnīcu, kas nīka bezdarbībā. Tolaik tautā pieauga apkures krāsniṇu popularitāte, un arī Valerija uzñēmīgais prāts pievērsās to izgatavošanai. Bet tad kāds interesents lūdza viṇam uzbūvēt kamīnu; sākumā uzṇēmējs attiecās, taču klients bija neatlaidīgs, un Valerijs, kurš pirms tam bija uzbūvējis tikai vienu kamīnu mūžā - sev, nolēma pamēgināt. Tas sanāca lielisks, un radās arvien jauni kamīnu būvēšanas pasūtījumi. Taču klientu daudz bija tikai rudens mēnešos, savukārt ziemā un pavasarī pasūtījumu nebija. Darba sezonālais raksturs un neregulārie ienākumi jau 90. gadu vidū V. Biteniekam lika saprast, ka vidējā alga gadā viṇam ir mazāka nekā palīgstrādniekam būvlaukumā [5]. Un atkal bija jādomā par darba mainu.

Inženieris V. Čmihovs piedāvāja V. Biteniekam uzbūvēt viṇam māju. Arī tās izmaksas (tāmi) aprēḳināja Valerijs. Tad Valerija studiju biedrs izlēma, ka labāk naudu ieguldīs biznesā - jaunajā koku žāvēšanas kaltē un lūdza viñam padomu: vai izdevīgāk celt pašiem, vai pirkt gatavu, saliekamo? Pēc nākamās tāmes izveidošanas tika pieṇemts lēmums būvēt pašiem. V. Bitenieks sāka strādāt pie drauga V. Čmihova, kurš savu pirmo kokzāgētavu Gaujā, netālu no Siguldas, atvēra 1990. gadā [11]. No pussabrukuša šķūṇa pamazām viṇš veidoja gateri, kurā sākumā bija tikai četri strādnieki [12]. Pateicoties koka eksportam un investoram no Vācijas, vecais gateris atdzīvojās un sāka nest pel̦nu. Tas no kooperatīva pārtapa par SIA «Gaujas Koks», un nu jau tas ir viens no pelnošākajiem uzṇēmumiem Latvijā. Būvējot koku žāvēšanas kalti, Valeriju iecēla par būvdarbu vadītāju četriem strādniekiem, kuri pirms tam strādāja gaterī. Lai gan par kaltēm, tāpat kā par kamīniem, Valerijs īsti neko nezināja, viňš sameklēja grāmatas, vakaros daudz lasīja un no rīta jau realizēja dzīvē, jo viṇam patīk teiciens: «Tie, kuri nezina, no kā baidīties - tie arī nebaidās». Tika uzbūvēts lielais korpuss ar katlumāju, trim kaltēm un ofisa telpām divos stāvos. Taču kādas nesaprašanās dēḷ V. Bitenieks no darba aizgāja, sāka būvēt kamīnus un apsvēra domu par sava uznēmuma dibināšanu.

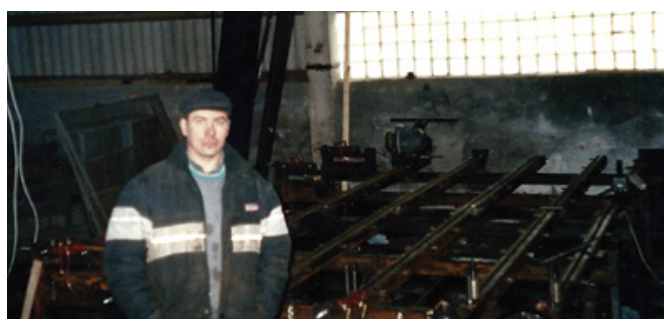

21. attēls. Valerijs Bitenieks panel̦u ražošanas ceha tapšanas laikā (2002). 
22. attēls. Koka panel̦u mājas celtniecība V. Bitenieka vadībā (2004).

23. attēls. V. Bitenieka veidotais kamīns Rīgā, Elizabetes ielā (1996).
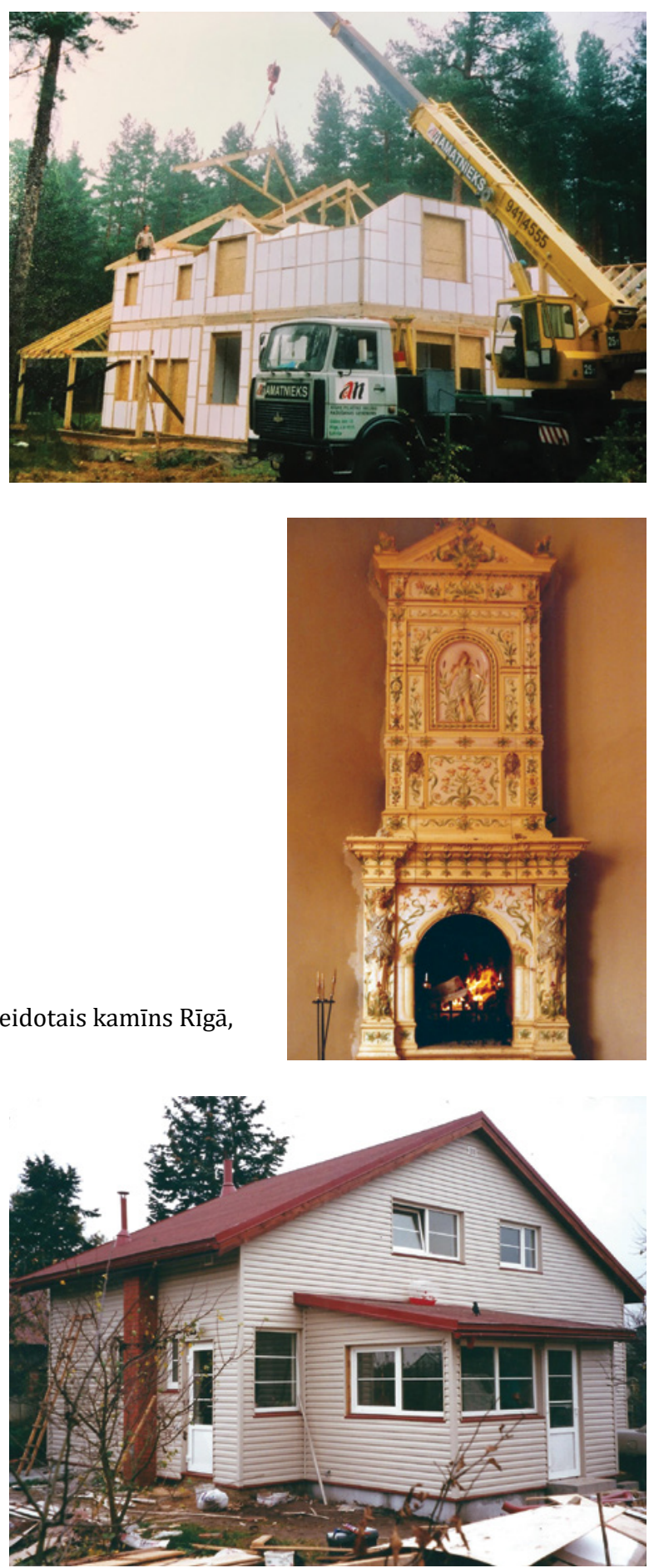

Ërika Lanka

\section{Valerijs}

Bitenieks - no

Rīgas Politehniskā institūta studenta līdz būvuznēmējam neatkarīgajā

Latvijā
24. attēls.

V. Bitenieka celtā māja (divu mēnešu laikā no pamatiem līdz jumtam) 2000. gada augustā. 


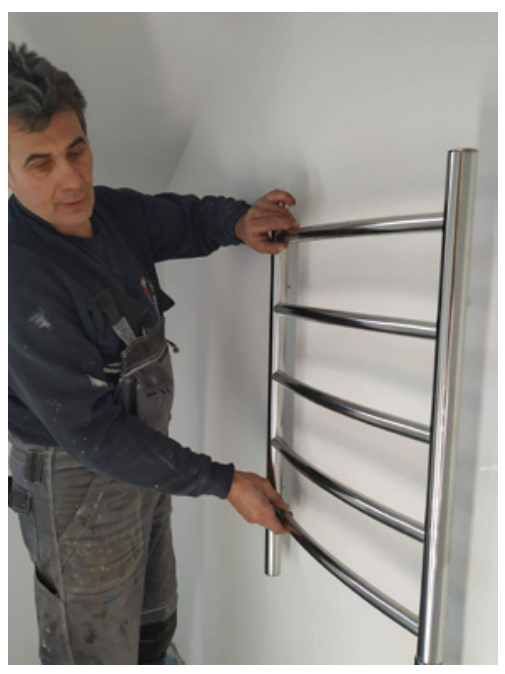

25. attēls. V. Bitenieks labiekārto renovētu māju (2021).

Tad sekoja uzṇēmēja un viesnīcas «Sigulda» īpašnieka Jura Dudko piedāvājums V. Biteniekam būvēt saliekamās koka mājas, ko izgatavoja Babītē reǵistrēts uzṇēmums «MJR». Pēc pāris māju uzbūvēšanas sekoja nākamais pasūtījums: vajadzēja rekordātrā laikā - divos mēnešos uzbūvēt māju no pamatiem līdz atslēgai, pārbūvējot to no dārza mājinas par dzīvojamo māju. Ar to celtnieki tika galā lieliski.

Vienlaikus V. Bitenieks secināja, ka mājas viṇš varētu būvēt arī pats, tikai nepieciešams investors. Interesi izrādīja tikai viens investors, kurš piedāvāja 3000 latu, taču ar to nepietika pat vienam kārtīgam darbagaldam. Uzṇēmēja, inženiera un celtnieka pieredze l̦āva par šo naudu radīt pilnīgi jaunu iekārtu (kurai nav analogu ārzemēs), ar kuru varēja sākt ražot panel̦us, ko paši arī montēja. Par šiem panel̦iem Valerijs Bitenieks kopā ar Edgaru Vasiḷevski 2003. gadā sanēma Latvijas patentu (LV 12971B «Sienas un pārseguma paneḷi mazstāvu èku būvniecībai»). Divos gados tika saražotas aptuveni 15 māju. Pēdējā - 2005. - darbības gadā trīs mēnešu laikā četri cilvēki cehā saražoja mājas ap $1200 \mathrm{~m}^{2}$ platībā, un vēl četri - tās montēja [5].

Uzṇēmēja gars Valerijam Biteniekam lika skatīties citā virzienā no panel̦u mājām pāriet uz masīvkoka karkasu mājām. Tam bija nepieciešams sadarbības partneris, taču to atrast neizdevās. Saprotot, ka ar savu ideju vinšs paliek viens, pieredzējušais celtnieks V. Bitenieks aizgāja strādāt būvbrigādē pie Siguldas uznēēēja Didža Turauska, kura firmā strādāja līdz 2008. gadam, kad tā bankrotēja, un atkal viss bija jāsāk no gala.

Kopš tā laika V. Bitenieks ir individuālais uzṇēmējs, kurš remontē un pārbūvē mājas, laiku pa laikam arī mūrējot kādu kamīnu. 
Valerija un viṇa sievas Ilmāras Bitenieku gimene 2022. gadā atzīmēs 40 gadu kāzu jubileju, vin,us priecē divas meitas - Linda un Lelde - un divi mazdēli - Austris un Ritvars.

26. attēls. Valerijs un Ilmāra Bitenieki kāzu dienā 1982. gada 25. decembrī Siguldā.

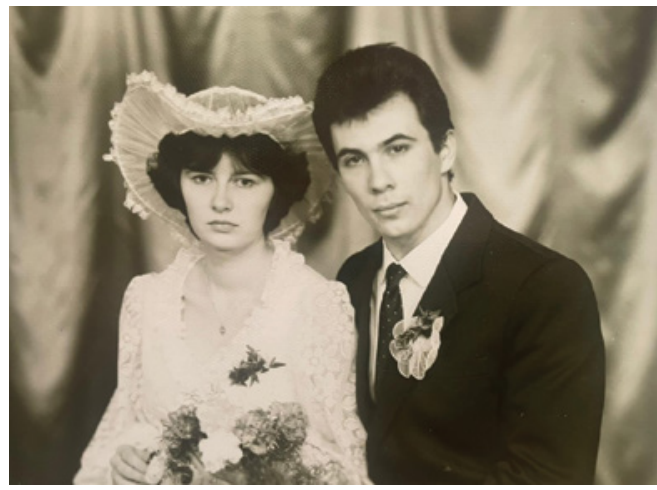

\section{Valerijs}

Bitenieks - no

Rīgas Politehniskā institūta studenta līdz būvuznēmējam neatkarīgajā

Latvijā

27. attēls. V. Bitenieks ar sievu Ilmāru Cēsu pusē Baltijas cel̦ā 1989. gada 23. augustā. V. Čmihova foto.

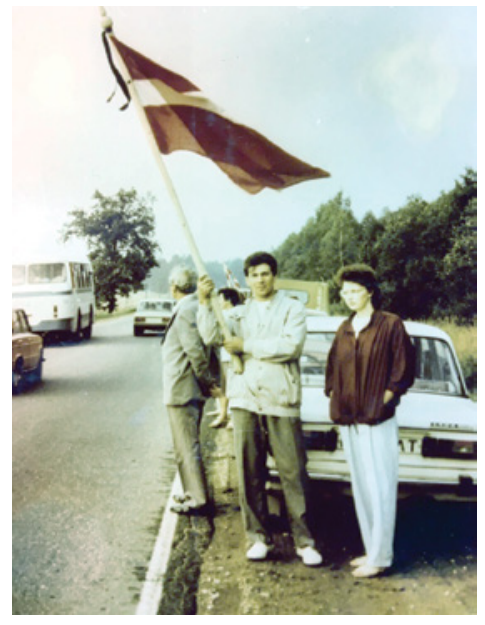

28. attēls. No kreisās:

V. Bitenieks, meita Lelde, sieva Ilmāra, meita Linda Rīgā (2010).

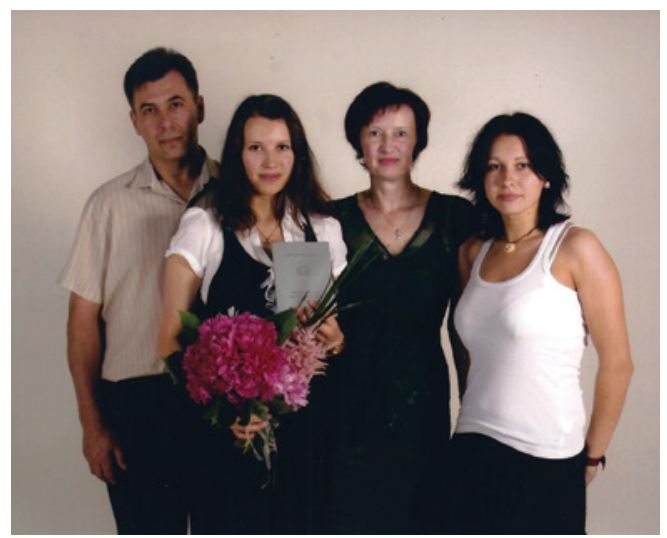




\section{Nobeigums}

RPI absolvents V. Bitenieks piedzima un auga padomju varas laikā 20. gadsimta otrajā pusē un bija viens no tiem, kuri vienmēr centās apsteigt laiku un definēt tālākus mērksus. Vin,š bija tipisks padomju laika students un savu sapni par augstskolas diplomu un inženiera specialitāti viṇš sasniedza. Būdams profesionālis, viņš centās godam nest būvinženiera vārdu gan padomju varas gados, gan atjaunotās Latvijas Republikas laikā un to turpina darīt joprojām. V. Bitenieks pieder tiem RPI absolventiem, kuri visu dzīvi velta iegūtajai specialitātei, vienmēr iet laikam līdzi, kā uzṇēmīgi profesionāḷi ar savām idejām apsteidz laiku un lepojas ar savu profesiju. V. Bitenieka profesionālā darbība un sasniegumi, tostarp cilvēciskās kvalitātes un ticība saviem spēkiem, ir devušas un joprojām dod lielu ieguldījumu Latvijai un tās būvniecības nozarei. Lai gan vairāk nekā puse no viṇa studiju grupas biedriem dzīvo un strādā ārzemēs, V. Bitenieks ir un būs Latvijas patriots, kurš savas augstskolā iegūtās zināšanas izmanto savu senču dzimtenē. Darbā ir svarīgas rakstura īpašības un dzīves vērtības, ko V. Bitenieks ieguva no saviem vecākiem un viṇu senčiem - pienākuma apziṇu no tēva, pedantismu no prūšu vecmāmin,as, goda izpratni un sirsnību no kazaku vecvecvecākiem, stratēgisku domāšanu no vectēva - Rucavas pagasta vecākā, interesi par reiki dziedniecību un budismu no savas burjatu vecvecvecmāmiñas.

Viṇš var būt paraugs tiem RTU studentiem, kuri tagad apgūst būvinženierzinātnes.

\section{ATSAUCES}

[1] Olgas Bitenieces personas dokumenti. Valerija Bitenieka personīgais arhīvs.

[2] Rucavas pagasta vēlēšanu dokumenti. Latvijas Nacionālā arhīva Latvijas Valsts vēstures arhīvs 4507. f., 1. apr., 6. l., 225. lp.

[3] Rucavas kooperatīva «Pašpalīdzība» pārskats par 1932. gadu. Kopdarbība, Nr. 6., 1933. gada 25. februārī, 6. lpp.

[4] Salmiṇš, G̦., Timbra, G. Ar Rucavas vārdu - lapu pa lapai: ieskats Rucavas vēsturē. Rucava: Rucavas novada dome, 2020, 244., 423. lpp.

[5] Ērikas Lankas intervija ar Valeriju Bitenieku 2020. gada 11. decembrī. $\bar{E}$. Lankas personīgais arhīvs.

[6] RPI studenta V. Bitenieka personāllieta. RPI/RTU arhīvs.

[7] Augstākās tehniskās izglītības vēsture Latvijā. 3. daḷa. Rīga: RTU, 2007, 96., 113. lpp.

[8] Alīdas Zigmundes intervija ar Valeriju Bitenieku 2021. gada 10. jūnijā. A. Zigmundes personīgais arhīvs. 
[9] Beḷavniece, V. ...Caurā akā ūdens nestāv. Padomju Jaunatne, 1987. gada 15. aprīlis, Nr. 74, 2. lpp.

[10] Mednis, I. Partiju laiki Latvijā (1988-2002). Rīga: Drukātava, 2007, 75. lpp.

[11] Būvinženieri Latvijai. Rīga: Latvijas Būvinženieru savienība, 2002, 21. lpp.

[12] TOP 10: Latvijas biznesa veterāni, kuri tirgū noturējušies vismaz 25 gadus Top2: Vitālijs Cmihovs «Gaujas koks» (100 \%). 17.11.2018 [tiešsaiste]. https://www.delfi.lv/bizness/biznesa_vide/top-10latvijas-biznesa-veterani-kuri-tirgu-noturejusies-vismaz-25gadus.d?id=50580923\&page $=9$ [skatīts: 10.01 .2021$]$.

\section{ILUSTRĀCIJU AVOTI}

1.-28. attēls. Valerija Bitenieka personīgais arhīvs.

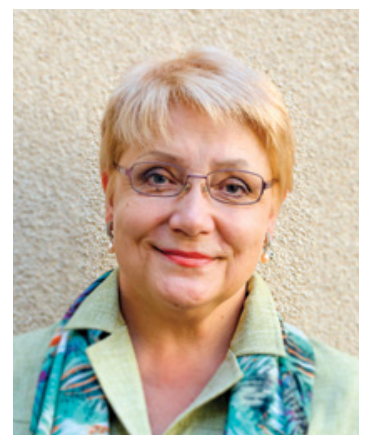

ĒRIKA LANKA, Mg. paed., Mg. phil., graduated from the University of Latvia. From 1984, she is a Lecturer at the Faculty of Education of the University of Latvia. From 2008 onwards she has worked as the Director of one of the Programmes at the Adult Pedagogical Education Centre (APEC) of the Faculty of Education, Psychology and Art. She participated as an expert in a lot of research projects in Latvia and abroad, at the same time she worked as a teacher at schools. Her main academic interests include the philosophy of education, ethics, axiology, values and codex of the teacher, history of pedagogy in Latvia and in Europe. She is the co-author of two monographies and the author of more than 42 publications.

Address: Imantas 7. linija, 1, Rigga, LV 1083, Latvia

Phone: +37129264829

E-mail:erika.lanka@lu.lv,erikalanka@inbox.lv

Érika Lanka

\section{Valerijs Bitenieks - from a Student of Riga Polytechnic Institute to a Construction Contractor in the Independent Latvia}

A paper on Valerijs Bitenieks, a graduate (1986) of the Faculty of Architecture and Civil Engineering of Riga Polytechnic Institute (RPI), reflects on the daily life of the Soviet students in the 1980s, the work of a young engineer while he was trying various opportunities in the labour market and the engineer's growth as a successful contractor in the independent Latvia in the 21st century. It traces the life of $V$. Bitenieks from his childhood to the present day, paying 
attention to his professional activities. The research provides an insight into students' internships and extracurricular activities during the Soviet era. Unpublished photographic material unknown to the general public has been obtained.

Keywords: Valerijs Bitenieks, Riga Polytechnic Institute, construction entrepreneurship. 